\title{
'Emergenza nomadi: Institutional Continuities in Italian Government Policy towards the Romanies
}

\author{
Riccardo Armillei \\ Swinburne Institute for Social Research \\ armillei.riccardo@gmail.com
}

\begin{abstract}
The Romani peoples today occupy a marginalised position in Italian society. A small number of these peoples live in 'camps' in conditions of extreme decay and abandonment. In order to address this situation and to improve these peoples' lives, the Italian government has recently decided to implement an 'extraordinary intervention.' In 2008, in continuity with previous centreleft governments, the Berlusconi right-wing coalition implemented the so called 'Emergenza Nomadi' (nomad emergency). The state of emergency aimed to solve an issue that had been already categorised in the 1970 as the 'problema nomadi' (nomads problem), and was now described and handled as a 'natural disaster.' Based on interviews with Romani individuals, institutional and Third Sector representatives, participant observation and a broad range of secondary sources, this article argues that the enactment of an extraordinary measure was both disproportionate to the real degree of threat, and perpetuated an institutional tradition of racism and control of the Romani peoples. It was not, as the declaration of an 'emergency' might imply, the result of a sudden, unexpected situation which required an immediate action. The 'emergency' and the premises for the implementation of a 'state of exception' were created by protracted institutional immobility and political vacuum.
\end{abstract}

Keywords: ‘Emergenza Nomadi,' Institutional Discrimination, Italy, Romanies.

\section{Introduction}

According to the most recent figures, there are between 130,000 and 180,000 Romani living in Italy: ${ }^{1}$ about half are Italian citizens, 20-25\% are from European Union countries, mainly Romania, while the rest are either non-EU members or stateless, as a result of the dissolution of the former Yugoslavia. ${ }^{2}$ The Romani communities constitute 0.2 per cent of the Italian population and only a small number of them (around 3 per cent) maintain a

\footnotetext{
${ }^{1}$ Commissione Diritti Umani del Senato, Rapporto conclusivo dell'indagine sulla condizione di Rom, Sinti e Camminanti in Italia [Final report on the condition of Rom, Sinti and Camminanti in Italy], 2011, <http://www.programmaintegra.it/modules/news/article.php?storyid=5691>, accessed 1 July, 2014, p. 18.

${ }_{2}^{2}$ European Roma Rights Centre (ERRC), osservAzione, \& Amalipé Romanò, Submission of the European Roma Rights Centre, osservAzione and Amalipé Romanò concerning Italy for consideration under the universal review by the United Nations Human Rights Council at its 7th session February 2010, 2010, <http://www.errc.org/cms/upload/media /04/29/mooo00429.pdf>, accessed 5 July, 2014, p. 1.
} 
'nomadic' life style. 3 Yet Italian Government policy is still based on the stereotypical assumption that all Romanies are 'nomads,' a term which describes them as unwilling or unable to settle within the host society, 'resisting the norms of territorialisation and cultural normalization.' 4 Because of this, they are considered as a national problem that must be addressed through extraordinary measures.

In Italy Romani peoples have been subjected to social exclusion and marginalisation for centuries. Only in the 1970 s did the Italian government begin to experiment with new forms of 'cultural protection' explicitly directed to the Romani communities. However these policies were based on the premise that Romanies were nomadic people. Nomadism was addressed as a problem 5 and all government interventions were focussed on the 'campo nomade' (nomad camp). ${ }^{6}$ This was to be the main means for the re-education and inclusion of these peoples within mainstream society. Every year a large amount of government funding is spent on managing the camps. This has piqued the appetites of different entities, both private and public. 7 A recent study reveals the existence of 'a legacy of "mutual accommodation" symbiosis between the non-profit and public sectors.'8 The main tendency, in fact, is for the State to abdicate its responsibility to non-profit organisations. The Romani issue has turned into a huge business in which it is very hard to know exactly how funds are actually used. 9 Administrations carry out forced evictions, breed new camps and violate human rights, instead of implementing social inclusion policies.

'Camp dwellers' and 'campi nomadi' can be understood as liminal subjects and spaces, whose relationship with institutions, Third Sector and mainstream society is best characterised by Agamben's notion of 'inclusive exclusion.'10 Romanies are neither included, nor absolutely excluded. They have a distinctive place within Italian society. Millions are spent every year on Romani-related issues. This has become an undertaking involving hundreds of employees, in public and private sectors alike. Rather than merely employ the language of 'othering,' 'marginalisation' or 'exclusion,' my analysis applies the concept of 'inclusive exclusion' to the approach adopted by Italian institutions in terms of 'inclusive exclusion.' On the one hand, the government invests significant sums in 'inclusion' projects; on the other it continues to promote the 'camps policy,' forced evictions and emergency measures. Public funds are used to promote a 'false' inclusion. ${ }^{11}$ Using Cemlyn and

\footnotetext{
3 Ministero dell'Interno, La pubblicazione sulle minoranze senza territorio [The publication on the stateless minorities], 2006, <http://www1.interno.gov.it/mininterno/export/sites/default/it/assets/files/13 /La_pubblicazione_sulle_minoranze_senza_territorio.pdf $>$, accessed 5 July 2014, p. 46. Commissione Diritti Umani del Senato, op. cit., p. 18.

4 E. Balibar, Foreword. In N. Sigona \& N. Trehan (Eds.), Romani politics in contemporary Europe: Poverty, ethnic mobilization, and the neoliberal order (pp. viii-xiii), New York, NY, Palgrave Macmillan, 2009, foreword xi.

5 L. Bravi \& N. Sigona, Educazione e rieducazione nei campi per "nomadi": Una storia [Education and re-education inside camps for "nomads": An overview]. International Journal of Migration Studies, Vol. 43, No. 164, pp. 857-874, $<$ www.osservazione.org/documenti/Sigona-Bravi.pdf>, accessed 10 June, 2012, p. 857.

${ }^{6} \mathrm{~L}$. Piasere, 'Les pratiques de voyage et de stationament des nomades en Italie' [Travel and short stay practices of the nomads in Italy] in A. Reyniers (Ed.), Les pratiques de deplacement, de halte de stationament des populations tsiganes et nomades en France (pp. 143-195), Paris, France, Centre de Recherches Tsiganes, 1985, p. 181.

7 M. Bonaccorsi \& R. Vazzana, Sui rom si fanno i milioni [Making Millions out of Roma], Left, 18 February 2011, <http://www.arcisolidarietaonlus.eu/content/sui-rom-si-fanno-i-milioni>, accessed 4 March 2012. C. Stasolla, Sulla pelle dei Rom: Il Piano Nomadi della giunta Alemanno [On the skin of the Romani Peoples: The Nomads Plan of the Alemanno's administration], Rome, Edizioni Alegre, 2012, p. 61.

8 M. Lori, Autonomous or dependent: Isomorphic effects of public regulation on voluntary organisations. Paper presented at 9 th International Conference of the International Society for Third Sector Research (ISTR), Istanbul, Turkey, July 2010, <http://www.istr.org/?WP_Istanbul $\geq$, accessed12 May, 2012, p. 22.

9 C. Cecchini, Oltre il campo: Tavola rotonda con testimonianze sulla condizione dei Rom a Roma [Beyond the camp: Round-table on the condition of the Romanies in Rome], Speech presented at Palazzo Valentini, Rome, 2012.

${ }^{10}$ G. Agamben, Homo Sacer: Sovereign power and bare life (Daniel Heller-Roazen, Trans.), Stanford, Stanford University Press, 1998, p. 22.

${ }^{11}$ Massimiliano Fiorucci, personal communication, December 20, 2011.
} 
Briskman's ${ }^{12}$ definition of 'dyswelfare,' I argue that service providers have failed 'to understand, respect and respond to different cultural values, lifestyles and strengths,' 13 which in turn has damaged the quality of Romanies' lives.

The relevance of Zygmunt Bauman's ${ }^{14}$ reflections on the phenomenon of global poverty help illuminate how the authorities have consigned Romanies to the status of 'human waste,' excluded from competing in the job market and relegated to marginalised areas. The Romani/'abjected' is never utterly irrelevant or absolutely useless and maintains a crucial relationship with the society/'abjector.' It constitutes the antithetical 'Other' in relation to which the abjector self is defined. The perception of Romanies as a threat is not caused by their presence or their arrival from foreign shores, but is actively fostered by the government through a well-established process of dehumanising the Romanies. In this context, the 'campo nomade' represents a tool for the social control of an allegedly dangerous people. Institutional immobility and indifference to their living conditions have rendered the Romanies an issue of national relevance and created the 'emergency' and the pretext for extraordinary measures.

\section{The Implementation of the 'Nomad Emergency'}

Between the end of 2007 and the beginning of 2008 a number of 'high-profile crimes allegedly committed by people of Roma ethnicity from Romania [were] extensively reported in the news, exacerbating aggressive anti-Roma rhetoric by local and national politicians.' 15 As a consequence, the presence of Romani peoples was associated with crime and addressed as a security issue for the Italian population. In particular, the violent murder of Mrs. Giovanna Reggiani, committed on the 3oth of October 2007 by a Romanian Roma in the city of Rome, brought the 'Nomads/Gypsies' issue to national attention. ${ }^{16}$ At the same time, the EU enlargement in January 2007, during the period of office of Romano Prodi's centreleft government, stimulated alarmism among Italians and fears of being invaded by immigrants from the new members of the European bloc, Romania and Bulgaria. ${ }^{17}$ This political issue exploded when the centre-left mayor of Rome Walter Veltroni resigned from office to become the national leader of the Democratic Party. ${ }^{18}$ According to Sigona, this led to 'a transplant of "local" issues into the national arena,' 19 eventually resulting in the enactment and implementation of two decree laws, also known as 'anti-Roma acts.'20

\footnotetext{
${ }^{12}$ S. Cemlyn \& L. Briskman, 'Social (dys)welfare within a hostile State,' Social Work Education, Vol. 21, No. 1, 2002, pp. 49-69.

13 Ibid., p. 49.

14 Z. Bauman, Wasted lives: Modernity and its outcasts, Cambridge, Polity Press, 2004.

15 Amnesty International, Italy: Briefing to the UN Committee on the Elimination of Racial Discrimination 8oth session February 2012, 2012, <http://www2.ohchr.org/english/bodies/cerd/docs/ngos/AI_Italy_CERD8o.pdf>, accessed 10 July 2014, p. 6.

${ }^{16}$ OsservAzione, The 'latest' public enemy: Romanian Roma in Italy. The case studies of Milan, Bologna, Rome and Naples, 2008, <http://www.osservazione.org /documenti/OSCE_publicenemy.pdf>, accessed 2 June 2011, p. 40.

${ }_{17}$ N. Sigona, "Gypsies out of Italy!": Social exclusion and racial discrimination of Roma and Sinti in Italy' in A. Mammone and G. Veltri (Eds.), Italy today: The sick man of Europe, London, UK, Routledge, 2010, p. 145.

${ }^{18}$ N. Sigona, 'The "Problema Nomadi" vis-à-vis the political participation of Roma and Sinti at the local level in Italy' in N. Sigona \& N. Trehan (Eds.), Romani politics in contemporary Europe: Poverty, ethnic mobilization, and the neoliberal order (pp. viii-xiii), New York, NY, Palgrave Macmillan, 2009.

19 Ibid., p. 287.

${ }^{20}$ Lunaria, Chronicles of ordinary racism: Second white paper on racism in Italy (D. Di Pietro \& C. Marshall, Trans.), Rome, Edizioni dell'Asino, 2011, p. 13.
} 
Although these agreements were said to be merely a way of curbing criminality, some of them made explicit reference to Romani peoples. ${ }^{21}$ In May 2007 the 'Patti per la Sicurezza' (Security Pacts) were signed by the Ministero dell'Interno and various local authorities, introducing a series of discriminatory measures which 'aimed at facilitating the removal of EU citizens from Italy whenever they were deemed to represent a threat to public and national security.' ${ }^{22}$ These measures authorised forced evictions of illegal encampments, without conforming to the procedural safeguards required under regional and international human rights standards. At the same time they had the effect of fuelling anti-Romani hysteria and violent attacks. ${ }^{23}$ Exactly a year later, on the 21st of May 2008, the initiative called 'Nomad Emergency' was launched. Initially it involved only the regions of Lombardy, Campania and Lazio, but in May 2009 it was also replicated by the regions of Piedmont and Veneto. The choice to implement an extraordinary approach, not only made a wrong use of both the terms 'nomads' and 'emergency' in relation to the Romani peoples, ${ }^{24}$ but also amplified a well-established tendency to disempower them.

Only as a result of national and international criticism did the government reframe the rationale of its intervention. New guidelines for the implementation of the ordinances of the President of the Council of Ministries of 30 May 2008, numbers 3676, 3677 and 3678 were issued. These argued that the extraordinary measures did not target any particular ethnic groups, but were actually motivated by the official aim to improve the living conditions of the Romani peoples. ${ }^{25}$ The claim that this was an issue of urgent national significance was used to justify the enforcement by law of a 'state of exception,' which, as theorised by Agamben, ${ }^{26}$ despite its initial provisional aim, slowly became the rule, extension after extension. According to Sigona, ${ }^{27}$ the 'emergency' had become a 'new permanent political category, ${ }^{28}$ which was merely used with the aim of containing a problem, rather than solving it definitively. Using a 1992 national service and civil protection law 29 the Italian government was able to present the Romani settlements as a threat to public order and security requiring the adoption of extraordinary means and powers. By Decree of the Council of Ministers, DCPM 21 May 2008, special powers were conferred on Prefects (permanent representatives of the national government in a particular territory), allowing them to derogate from a number of existing laws. 30

\footnotetext{
${ }^{21}$ Office for Democratic Institutions and Human Rights, Assessment of the human rights situation of Roma and Sinti in Italy: Report of a fact-finding mission to Milan, Naples and Rome on $20-26$ July 2008, 2009, <http://www.osce.org/odihr/36374>, accessed14 December, 2012, p. 16.

${ }^{22}$ OsservAzione, op. cit., p. 3.

${ }_{23}$ ERRC, osservAzione, \& Amalipé Romanò, op. cit., p. 8.

${ }^{24}$ Amnesty International, The wrong answer. Italy: The "Nomads Plan" violate the housing right of the Romani people in Rome, 2010, <www.amnesty.it>, accessed 14 April, 2012, p. 4.

25 Ministero dell'Interno, Linee guida per l'attuazione delle ordinanze del presidente del consiglio dei ministri del 30 maggio 2008, n. 3676, 3677 e 3678, concernenti insediamenti di comunità nomadi nelle regioni Campania, Lazio e Lombardia [Guidelines for the implementation of the ordinances issued by the President of the Council of Ministries of 30 May 2008, nos. 3676, 3677 and 3678], 2008, <http://www.interno.it/mininterno/export/sites/default/it/assets/files/15/oo95_censimento_campi_nomadi_le_linee guida.pdf $>$, accessed 10 May 2012, p. 1.

${ }_{26}$ Agamben, op. cit., p. 169.

${ }_{27}$ N. Sigona, Figli del ghetto: Gli italiani, i campi nomadi e l’invenzione degli zingari. [Sons of the ghetto: Italians, Nomad Camps and the invention of the Gypsies], Civezzano, Nonluoghi, 2002.

${ }^{28}$ Ibid., p. 86.

${ }_{29}$ Amnesty International, Italy: Briefing to the UN, op. cit., p. 6. "Under Law 225/1992 on the establishment of the civil protection service, the Council of Ministers may declare a state of emergency to respond to natural calamities, catastrophes or 'other events which owing to their intensity and extent have to be confronted with extraordinary means and powers"'(Ibid., p. 6).

$3^{30}$ Amnesty International, The wrong answer, op. cit., p. 4.
} 
The Romani peoples were thus compared to a sort of 'natural disaster' and 'paradoxically the emergency didn't relate to the shameful conditions that [they] have been forced to endure, but rather to their presence itself.' ${ }^{31}$ Although the government had argued differently, the 'Nomad Emergency' appeared to be ethnically motivated. It introduced:

The monitoring of formal and informal camps, identification and census of the people (including minors) who are present there, and taking photos ('mug shots'); the expulsion and removal of persons with irregular status; measures aimed at clearing 'camps for nomads' and evicting their inhabitants; as well as the opening of new 'camps for nomads.' 32

Since the great majority of the camp dwellers were of Romani background this rendered them the sole target of the measures adopted by the government, thus replicating the premises underlying the previous Security Pacts. As Favero33 argues, the main concern for the authorities was, in fact, the protection of the 'good' Italian local population against the allegedly 'bad/dangerous' Romani peoples. 34 The Italian government, supported by a condescending mainstream society, pushed for the implementation of restrictive measures which reflected a widespread conception of the Romanies as an 'biological threat,' or even a 'degenerate' group, that had to be either kept separate from the rest of the society or moved away. 35

Following legal action which was started in 2008 by the ERRC, on the 16th of November 2011, the 'Nomad Emergency' was eventually declared 'unfounded and unsubstantiated' by the Italian Council of State, the highest administrative court. ${ }^{6}$ Despite the annulment of the ordinance that had introduced the State of Emergency, most of its legal and practical consequences still persisted. 37 The resulting legacy continued to affect the way public policies were tailored for Romani peoples. For instance, following Berlusconi's resignation on 16 November 2011, the new Prime Minister, Mario Monti, tried to re-enact the 'Nomad Emergency.' 38 On 15th February 2012, the Monti government appealed the decision of the Council of State before the Court of Cassation. A few months later, on 9 May 2012, the Council of State suspended the implementation of its previous ruling, pending the decision from the Court of Cassation. 39 The appeal made by the new Prime Minister was, however, contradictory. On 28th February 2012, the Monti government had launched a National Strategy for the inclusion of the Romani communities with the declared aim of definitively

\footnotetext{
${ }^{31}$ M. Fiorucci, Un'altra città è possibile. Percorsi di integrazione delle famiglie Rom e Sinte a Roma: Problemi, limiti e prospettive delle politiche di inclusione sociale [Another city is possible. Integration trajectories of Rom and Sinti families in Rome: Problems, limitations and perspectives of social inclusion policies], Roma, Italia: Geordie Onlus, 2010 , p. 34.

$3^{2}$ ERRC, osservAzione, \& Amalipé Romanò, op. cit., p. 18.

33 P. Favero, 'Italians, the "good people": Reflections on national self-representation in contemporary Italian debates on xenophobia and war,' Outlines - Critical Practice Studies, No. 2, 2010, pp. 138-153.

34 Ibid., p. 148.

35 I. Clough Marinaro, 'Between surveillance and exile: Biopolitics and the Roma in Italy,' Bulletin of Italian Politics, Vol. 1, No. 2, 2009, pp. 265-287.

${ }^{6}$ Amnesty International, Italy: Briefing to the $U N$, op. cit., p. 8.

Ufficio Nazionale Antidiscriminazioni Razziali (UNAR), Strategia Nazionale d'inclusione dei Rom, dei Sinti e dei Caminanti: Attuazione comunicazione commissione europea n.173/2011 [National Strategy for the Inclusion of Roma, Sinti and Camminanti Communities: European Commission communication no. 173/2011], 2012, <http://ec.europa.eu/italia/documents/attualita/aff_sociali/roma_italy_strategy_it.pdf >, accessed 5 June 2011 , p. 11. 37 Amnesty International, Italy: Briefing to the UN, op. cit., p. 9.

38 Y. Sina, Rom: Il governo ci riprova [Roma: The government tries again], Il Manifesto, 3 April 2012, <http://www.giustizia-amministrativa.it/rassegna_web/120403/1d3exz.pdf>, accessed 3 February, 2012, para. 1.

39 Associazione 21 Luglio, Association for Juridical Studies on Immigration, Amnesty International, Human Rights Watch, \& Open Society Justice, Italy: Leave "Nomad Emergency" in the past, 2012, <http://www.statewatch.org/news/2012/may/italy-nomad-emergency-press-release.pdf>, accessed 12 July 2013 , p. 1.
} 
overcoming "the emergency phase, which has characterised the past years.' 40 In July 2012, as noted by Nils Muižnieks, Commissioner for Human Rights of the Council of Europe, after his visit to Italy, the emergency approach was yet to be abandoned. ${ }^{41}$

\section{Problematising History as a Temporal Continuum}

Since political unification in 1861, Italy has experienced a number of changes evolving 'from a poor, backward and agrarian economy to a rich and industrial economy; [going] through bouts of economic insularity and integration; [swinging] from massive emigration to large immigration.' 42 Since then, three main features have played a key role in shaping government policies towards cultural diversity, as well as the identity of the Italians as a nation, namely: a history of authoritarian tendencies, a monoculture catholic national narrative and well-established racist attitudes. These issues have never been adequately analysed or politically addressed, thus affecting the democratic process and preventing the social inclusion of 'otherised' communities, Romani peoples in particular.

It is possible to divide the history of Italy as a nation-state into several major phases: the post-unitary Liberal period; the 'ventennio fascista' (1922-1943); the 'First Republic' (19481992); the 'Second/Third Republic' (from 1994 onwards). Each of these phases retains very peculiar configurations and meanings. At the same time, though, they show interconnectedness, which was also influenced by the broader international context.

Today the lack of an in-depth and cohesive analysis aiming at showing similarities and common features of these different political stages is an obstacle to the acknowledgment of government approaches as a 'temporal continuum.' In the following sections I will thus draw attention to continuities between these historical periods, in order to demonstrate the existence of recurring themes in the Italian politics. The Fascist era for instance, generally acknowledged as the darkest page in Italian history, is often described as if this was a mere casualty in the process of democratic nation building, while its earlier origin and/or its legacy with post-war policymaking are minimized.

Romani minority groups were interned and exterminated during the Second World War ('Porrajmos' in the Romani language). To this day, it is politically acceptable to pursue the institutionalization of Romanies in 'campi nomadi' (nomad camps) and to introduce a state of emergency in order to do so. That this policy could be implemented without provoking public discomfort suggests an ongoing legacy of Fascist/Nazi persecution in Italian society.

\section{From Risorgimento to the Fascist Regime: Between 'Inward' and 'Outward' Colonialism}

\footnotetext{
40 UNAR, op. cit., p. 3 .

${ }^{41}$ Commissioner for Human Rights, Report by Nils Muižnieks Commissioner for Human Rights of the Council of Europe following his visit to Italy from 3 to 6 July 2012, 2012, <https://wcd.coe.int/com.instranet.InstraServlet?command=com.instranet.CmdBlobGet\&InstranetImage=2143096\&Se cMode $=1 \&$ DocId $=1926434 \&$ Usage $=2>$, accessed 20 August, 2013, p. 3 .

${ }^{42}$ M. Fratianni, '150 years of Italian political unity and economic dualism: An Introduction,' Rivista Italiana degli Economisti, Vol. 17, No. 3, 2012, pp. 335-346.
} 
'Italian Fascism did not suddenly appear from nowhere.' 43 The failures of the previous liberal governments contributed to Mussolini's rise to power. 44 The Liberal period after unification was indeed 'illiberal' and unpopular, leading to the explosion of a first, mainly forgotten, 'civil war' in the South, 45 which was ultimately suppressed by government force. The conquest of the peninsula by the Kingdom of Sardinia was the result of the Northern imperialism ${ }^{46}$ rather than of romantic nationalism of popular insurrection. The 'people', urban workers and peasants were mere 'spectators of the Risorgimento.' 47 The remark made by the politician Massimo D'Azeglio to the Italian king Victor Emmanuel II indicated that Italy was still an aspiration yearned only by a small elite: 'Sir, we have made Italy. Now we must make Italians.' 48

During this Liberal era Italy initiated its imperialistic endeavor both as a question of prestige, and also to establish a new sense of unity throughout the country by transferring the Risorgimento's values into the new colonial logic. As Re49 argues, in the final years of "Liberal Italy" (1870-1914), and particularly under the leadership of Prime Minister Francesco Crispi first, and then of Giovanni Giolitti, [racism, colonialism and imperialism] came increasingly to be defining traits of the Italian national identity.' However the Italian military campaigns were extremely unsuccessful. The historic catastrophe at Adowa in 1896 against the Ethiopians, the war in Libya, and later the decision to participate in the First World War proved fatal for the liberal governments. A deep post-war economic crisis and a 'mutilated victory' laid the basis for the establishment of a totalitarian state. 50

The peculiarity and major strength of the new regime was due mainly to Mussolini's ability to re-unite the country through a subtle strategy of re-composition of the many internal divisions, which had been exacerbated over the years by the failures of the previous liberal governments. First of all, Mussolini recognised the significance of the Church, which was able to exert 'a considerable amount of control and influence over the people, in particular, the peasantry, while minimizing anti-clerical feelings within the Fascist party.' ${ }^{1}$ Secondly, by creating a cult of personality, $5^{2}$ he promoted an ardent nationalism, while also exalting and reviving the eternal grandeur of the past Roman Empire, through war and colonialism.53 Mussolini was finally able to 'make Italians' and to establish a collective sense of identity. This was something that the liberal state had failed to accomplish. 54 At this point in Italian

43 J. F. Pollard, The Fascist Experience in Italy [E-reader version], 2005, <http://www.e-readinglib.org/bookreader.php/135877/The_Fascist_Experience_in_Italy.pdf>, accessed 2 June 2011, p. 133.

$44 \mathrm{~K}$. Roberts, The rise of Italian Fascism, 2010, <http://www.docstoc.com /docs/28120434/The-Rise-of-ItalianFascism>, accessed 1 August 2011, p. 1.

45 Ibid., p. 2.

${ }^{46}$ Ibid., p. 2. L. Re, 'Italians and the invention of race: The poetics and politics of difference in the struggle over Libya, 1890-1913,' California Italian Studies, Vol. 1, No. 1, 2010, <http://escholarship.org/uc/item/96k3w5kn>, accessed 25 March 2011, p. 18.

47 N. Carter, Modern Italy in historical perspective, 2010, <http://www.bloomsburyacademic.com/view /ModernItaly_9781849662109/preface-ba-9781849662109-preface-001.xml>, accessed 5 December 2011, Debates, para. 14.

${ }^{48}$ M. Collier, Italian Unification, 1820-71, Oxford, UK, Heinemann Educational Publishers, 2003, p. 4.

49 Re, op. cit., p. 8.

$5^{\circ}$ Roberts, op. cit., p. 3.

${ }^{1}$ Ibid., p. 2.

${ }^{2}$ R. A. Ventresca, A comparative history of regime change: Transitional justice in post-war Italy and post-Saddam Iraq, Paper presented at the conference 'After the fall: Theory and practice of post-intervention security,' Centre for Security and Defence Studies, Carleton University, Ottawa, 2006, p. 8.

53 P. Pezzino, 'The Italian resistance between history and memory,' Journal of Modern Italian Studies, Vol. 10, No. 4, 2005, pp. 396-412. Pollard, op. cit., p. 105.

54 Carter, op. cit., p. 240. 
history, the Libyan war came to symbolize this achievement, while also reflecting the longterm continuities between Liberal and Fascist Italy. .55

Mussolini had succeeded in re-activating a number of latent Risorgimento topoi, such as the sense 'of belonging to a distinct racial family, ethnic community, or 'stock' (however composite and historically stratified).' ${ }^{6}$ In particular he was able to transfer this idea to all those categories, such as women, Catholics, Jews, peasants, and Southerners, that since then had been excluded from the birth of the nation and the patriotic rhetoric. According to Re a new shared identity was created and strengthened through the logic of colonization racialised 'otherness outside rather than inside the nation's borders.' 57 At the same time, the Fascist regime made use of propaganda, violent repression and social control in order to eliminate internal opposition. At the end of the long 'ventennio fascista', a cruel civil war exploded throughout the peninsula in response to these conflicts. 58

The conclusion of the Second World War determined the emergence of new problems. An international war crime tribunal on the model of the Nurnberg and Tokyo trials in Germany and Japan, was never established in the new emerging republican Italy. 59 For this reason, as Ventresca ${ }^{60}$ explains, since the end of the war, Italians have never developed a shared understanding and knowledge of their past, leading to the promotion and internalization of the myth of the Italians as 'brava gente' or good people. ${ }^{61}$

\section{The Romani Persecutions: An Overview}

Since their first appearance in Europe, Romani peoples have been regarded as 'outcasts, intruders, and threats, probably because of their dark skin, their association with invading Muslim Ottoman Empire, and their foreign ways.' 62 The particular marginalised position which many Romanies still occupy today within many European contexts can be also described as the effect of a long-standing negative association with the concept of nomadism. This went together with the idea that a civilizing mission was necessary to correct it. Already during the eighteenth century policies were implemented for the sedentarisation, or rather forced assimilation, of the Romani minorities. 63

A series of institutional measures was put into place to tackle nomadism. Not long after their arrival, the first Romani communities 'began to be treated as a public danger and subjected to bans throughout the Italian peninsula.' 64 According to Spinelli, 65

\footnotetext{
55 Re, op. cit., p. 6.

${ }^{5}$ Ibid., p. 8.

57 Ibid., p. 9.

$5^{8}$ A. Mammone, 'A daily revision of the past: Fascism, anti-Fascism, and memory in contemporary Italy,' Modern Italy, Vol. 11, No. 2, 2006, pp. 211-226.

59 Ventresca, A comparative history, p. 18.

${ }^{60}$ R. A. Ventresca, 'Debating the meaning of fascism in contemporary Italy,' Modern Italy, Vol. 11, No. 2, 2006, pp. 189209.

61 Pezzino, op. cit., p. 402.

${ }^{62}$ C. Silverman, 'Persecution and politicization: Roma (Gypsies) of Eastern Europe,' Cultural Survival Quarterly, Vol. 19, No. 2, 1995, pp. 43-49, <http://www.culturalsurvival.org/publications/cultural-survival-quarterly/albania /persecutionand-politicization-roma-gypsies-eastern $>$, accessed 4 May, 2011, para. 8.

63 UNAR, Vai oltre $i$ pregiudizi, scopri $i$ Rom: Go beyond prejudice, discover the Roma, 2011, <http://www.cominrom.it/wordpress/wp-content/uploads/2011/11/Volume_Campagna-Dosta_UNAR.pdf >, accessed 5 December, 2012, p. 31.

64 G. Viaggio, Storia degli zingari in Italia, Centro Studi Zingari, Roma, 1997, cited in Clough Marinaro, op. cit., p. 271.

${ }_{5}$ S. Spinelli, Rom, genti libere: Storia, arte e cultura di un popolo misconosciuto [Roma, free people: History, art and culture of an unrecognised people], Dalai Editore, Milan, 2012, p. 84.
} 
between 1483 and 1785, approximately 210 orders were issued against Romani peoples. [...] At the beginning those edicts, bans and orders decreed a mere obligation to leave the territory. Transgressors could be imprisoned or whipped. Later on, though, disciplinary measures became wider and penalties exacerbated, on the wake of the European trend.

Particularly in the late 18th century, in the context of emerging ethnic nationalism, ${ }^{66}$ the Romanies were perceived to be a problem of national security, demanding their extreme measures of control. After the Risorgimento, the newly unified Italian nation-state introduced the first policies specifically directed at controlling 'vagabonds' and 'socially dangerous' groups, such as the Romani peoples. ${ }^{67}$ The Romanies became the main catalyst for Italians' fears regarding the purity of their national identity.

By appealing to a nationalistic rhetoric, but also recurring to normative and educational processes, the State became the guarantor of the transmission and maintenance of a new cultural order. ${ }^{68}$ In a time dominated by a positivist approach, where the only truth was scientific knowledge, the resistance displayed by itinerant people to the 're-educational' policies enacted within different national contexts was soon associated with racial features. ${ }^{69}$ The work L'Uomo Delinquente (Criminal Man) published in 1878 by Cesare Lombroso, an Italian criminal anthropologist, supplied scientific underpinning to this common belief, presenting the view of the 'Zingari' (Gypsies) as a criminal race. $7^{\circ}$ Influenced by the Darwinist theory, Lombroso argued that not only it was possible to identify criminals through the use of anthropometric techniques, but that certain attributes, considered responsible for creating inferior populations among the species, were hereditary. For this reason in order to preserve human societies, Lombroso 'believed that deliberate selection was appropriate, to complement and fortify natural selection.' 71

As in other parts of Europe, in Italy the pinnacle of segregative practices against the Romani peoples was reached in the 1940s. At that time they started to be imprisoned in concentration camps, such as Agnone, Arbe, Boiano, Cosenza, Gonars, Perdasdefogu, Prignano, etc., because they were considered by the fascist regime to be socially and racially dangerous. ${ }^{72}$ In many cases, Romani children were subjected, during their detention, to a process of re-education through which they were taught about discipline, fascist history and religion. In Agnone, for instance, 'until 1943 there was a camp reserved especially for "gypsies." 73 The imprisonment of the Romani peoples was a direct consequence of a 'cleansing activity' that the fascist dictatorship had launched in 1926, when a circular was

\footnotetext{
${ }^{66}$ P. H. O’Neill, Essentials of Comparative Politics, $3^{\text {rd }}$ edn, W W Norton \& Company, New York, 2009.

${ }^{67}$ Clough Marinaro, op. cit., p. 272.

${ }^{68}$ F. Pompeo, Il mondo è poco: Un tragitto antropologico nell'interculturalità [The world is little: An anthropological journey in the interculturality], Meltemi Editore, Rome, 2002, p. 68.

69 L. Bravi \& N. Sigona, op. cit., p. 858.

${ }^{70}$ C. Lombroso, L’Uomo Delinquente [Criminal Man], Torino, Bocca, 1878, cited in G. Baldini, G. Baldoni, I. D'Isola, G. Frassanito \& M. Sullam (eds), Alla periferia del mondo: Il popolo dei rom e dei sinti escluso dalla storia [At the fringes of the world: The Romani peoples excluded from history], Insmli \& Fondazione Franceschi, Milan, 2003, p. 57.

${ }^{71}$ C. Lombroso, L'Uomo Delinquente [Criminal Man], Torino, Bocca, 1878, cited in G. Cavaglion, 'Was Cesare Lombroso Antisemitic?,' The Journal for the Study of Antisemitism, 2011, Retrieved from <http://www.jsantisemitism.org/essays/Cavaglion\%20\%282\%29.pdf>, accessed 7 March 2012, p. 303.

${ }^{72}$ Bravi \& Sigona, op. cit., p. 860.

73 L. Bravi, The history of the Roma and Sinti in Nazi-Fascism, 2009, <http://www.theforgotten.eu /index.php?option=com_content\&view=article\&id=58\%3Ala-storia-dei-rom-e-sinti-nel-nazi-fascismo-di-lucabravi\&lang=en>, accessed 4 June 2011, para. 7.
} 
issued ordering the expulsion of all foreign Romanies. ${ }^{74}$ According to a recent report issued by the Commissione Diritti Umani del Senato, despite the terrible price paid by this population as a result of a widespread 'anti-Gypsism' all over Europe, there is not much historical data about the persecution of the Romani peoples in Italy during the fascist regime and it is thus not possible to clearly determine the dimension of this phenomenon. [...] The genocide of the Romani peoples is a forgotten event. 75

\section{The Long Dominance of the Christian Democracy: An Unfinished Republican Transition}

As Pedaliu 76 argued, in a few years' time 'the issue of Italian war criminality was conveniently forgotten as the Cold War became the main determinant of inter-national relations in the postwar world and the consolidation of the anti-communist bloc became an imperative.' 77 The risk of a new red invasion in Europe had pushed the Italian government, as part of a larger Western strategy, to drift towards anti-democratic authoritative measures. In this context, fascists came to play a key role as an anti-communist entity just as they had at the end of the Great War. ${ }^{78}$ From the end of the Second World War and almost for the entire period of the Cold War, the Italian political scene has been dominated by Christian Democratic (DC) governments. In the aftermath of the Second World War, the Church represented the main surviving institution. 79 Under heavy American influence and with a 'limited sovereignty,' Italy was called to form a 'front state' in the Cold War era, 80 with the aim of preventing both communists and neo-fascists from coming to power.

The post-war Italian political scene was influenced by the so called 'strategy of tension,' which was coordinated by the America intelligence CIA and part of a larger NATO plan in Europe also known as 'stay-behind.' 81 This had enabled the DC to remain firmly in power. One of the most controversial aspects of the 'stay-behind' strategy was its involvement of former fascist militants and organizations, which, in the period from the late 1960s till the early 1980s, the so called 'Years of Lead,' made systematic use of terroristic bombings for political reasons. ${ }^{82}$ According to Celani, during this timeframe 'there were at least four known coup d'état attempts' 83 possibly aiming at establishing a military state. Although 'both left- and right wing terrorists conducted attacks in the 1970s, [those carried out] by right wing groups, were falsely blamed on left-wing groups,'84 with the hidden support of

\footnotetext{
74 Council of Europe, Human rights of Roma and Travellers in Europe, 2012, <http://www.coe.int/t/commissioner/source/prems/prems79611_GBR_CouvHumanRightsOfRoma_WEB.pdf>, accessed 12 March 2013, p. 7.

75 Commissione Diritti Umani del Senato, op. cit., p. 36.

${ }^{76}$ E. G. H. Pedaliu, 'Britain and the "hand-over" of Italian war Criminals to Yugoslavia, 1945-48,' Journal of Contemporary History, Vol. 39, No. 4, 2004, pp. 503-529.

77 Ibid., p. 504.

${ }^{78}$ Roberts, op. cit., p. 5 .

79 N. Sitter, Civil war politics - the 'first' Italian republic: The institutionalization of the civil war cleavage in post-1945 Italian party politics, paper presented at the 50th Annual Conference of the Political Studies Association, London, UK, April 2000, p. 5.

8o J. W. Müller, The paradoxes of post-war Italian political thought, 2008, <http://www.princeton.edu/ jmueller/HEIITA-Thought-JWMueller-22Sept2008->, accessed 15 February 2011, p. 2.

${ }^{81}$ C. Celani, 'Strategy of tension: The case of Italy,' Executive Intelligence Review, Vol. 31, No. 12, 2004, pp. 34-39.

82 F. Gallego, The extreme right in Italy: From the Italian social movement to post-fascism, 1999, <http://www.recercat.net/bitstream/handle/2072/1295/?sequence=1>, accessed 15 February 2011.

83 Celani, op. cit., p. 38.

84 Transnational Terrorism, Security, and the Rule of Law. 2oth century right wing groups in Europe: Prone to extremism or terrorism?, July 2008, <http://www.transnationalterrorism.eu/tekst/publications /Rightwing\%20terrorism.pdf>, accessed 10 May 2011, p. 12-13.
} 
secret services and public institutions. The ultimate goal was the creation of 'an anticommunist climate and increase the public support for the state.' 85

Although it was officially celebrated as a democratic political system, the Italian 'Fïrst Republic' from 1948 until 1992 perpetuated an authoritarian government approach. As Pollard puts it, "the "Christian Democratic regime," [echoed] the "Fascist regime" 86 with its secretive and systematic use of un-democratic tools. At the same time, the "strategy of tension' was combined with one of political 'dominance,' leading to the 'institutionalization of the civil war cleavage,' and characterised by a 'permanent government - opposition relationship.' 87 Although stable to a high degree, 88 this period should be interpreted as a 'de facto colonization of the Italian state by the DC.' 89 The main anomaly of the Italian democratic system up to the 1990s, when the 'Mani pulite' (clean hands) scandal exploded, is the existence of a well-rooted mechanism of institutional corruption involving both government and opposition. ${ }^{\circ}$ But the so called "revolution of the judges" [...] proved to be of short duration.'91 The moral regeneration of Italian politics never occurred.

After the fall of the 'First Republic' political theorists and scholars have been divided regarding the analysis of the new historical conjuncture and its effects on the Italian democratic system. Some analysts, such as Agnew, 92 Fabbrini, 93 Gallego, 94 Rasner 95 and Sitter ${ }^{96}$ have theorized the natural shift from a 'First' to a 'Second' or sometimes 'Third' Republic. Others, Diamanti, 97 Edwards 98 and Vannucci, 99 have questioned the analytical relevance of this conceptualization. Diamanti, for instance, argues that the Italian party system is in a sort of permanent transition, suggesting that 'an unsettled phase of change, is actually a condition of stable instability.' 100 Vannucci identifies a supposed transition lacking any underpinnings in terms of formal constitutional change, but capturing the dramatic quality of this political conjuncture. ${ }^{101}$ Edwards as well argues that 'after nearly two decades of 'transition' and with no endpoint in sight, the model has lost its explanatory force.'102 According to him 'the Italian Republic has been “in transition” since 1948.'103

\section{From Protection to Segregation: The 'Campization' of the Romani Peoples}

\footnotetext{
85 Ibid., p. 13.

${ }^{86}$ Pollard, op. cit., p. 139.

87 Sitter, op. cit., p. 1. policies,' Bulletin of Italian Politics, Vol. 1, No. 2, 2009, pp. 233-264.

89 Müller, op. cit. p. 8.

90 Pizzorno, La politica assoluta, Milano, Feltrinelli, 1993, cited in Vannucci, op. cit., p. 235.
}

${ }^{88}$ A. Vannucci, 'The controversial legacy of "mani pulite": A critical analysis of Italian corruption and anti-corruption

${ }^{91}$ D. Della Porta \& A. Vannucci, 'Corruption and anti-Corruption: The political defeat of “Clean Hands” in Italy,' West European Politics, Vol. 30, No. 4, 2007, pp. 830-853.

${ }^{2}$ J. Agnew, 'Remaking Italy? Place configurations and Italian electoral politics under the "Second Republic," Modern Italy, Vol. 12, No. 1, 2007, pp. 17-38.

93 S. Fabbrini, 'The transformation of Italian democracy,' Bulletin of Italian Politics, Vol. 1, No. 1, 2009, pp. $29-47$.

94 Gallego, op. cit., p. 12.

95 A. Rasner, Success and failure in public pension reform: The Italian experience (Unpublished Bachelor's thesis), 2002, <http://www.demogr.mpg.de /publications\%5Cfiles\%5C3052_1205230445_1_PDFVersion.pdf>, accessed 15 July, 2012. ${ }^{96}$ Sitter, op. cit., p. 1.

97 I. Diamanti, 'The Italian centre-right and centre-left: Between parties and "the party," West European Politics, Vol. 30, No. 4, 2007, pp. 733-762.

98 P. Edwards, "Alternation? What Alternation?" The Second Republic and the challenge of democratic consolidation,' Bulletin of Italian Politics, Vol. 3, No. 2, 2011, pp. 319-342.

99 Vannucci, op. cit., p. 234.

${ }^{100}$ Diamanti, op. cit., p. 755 .

101 Vannucci, op. cit., p. 234.

102 Edwards, op. cit., p. 319.

103 Ibid., p. 319. 
In a work published in 2000 by the ERRC, Italy has been iconically defined a 'Campland' because it is the only country in Europe promoting a policy of segregation of the Roma population inside 'ghetto-like urban camps.'104 More than a decade later, the strategy of housing Romani peoples inside institutional camps still represents the pivotal measure used by the Italian government to ensure the social 'inclusion' of this minority group. As Clough Marinaro and Sigona argued,

they are the most visible expression of Roma's social exclusion and are consequently the primary focus both of popular anti-Gypsism and institutional repression and control. While many camps are being demolished because of their dire living conditions, others are being built by the same authorities to continue warehousing an ethnic group for which few alternative policy approaches are devised. ${ }^{105}$

The institutional policy of using camps for the 'nomadic' Romanies has been also acknowledged as uniquely Italian solution by UNAR. ${ }^{106}$ Piasere dates the 'politics of the camps' to the middle of the twentieth century. ${ }^{107}$ For Piasere this government policy was not elaborated as the result of a specific national choice, but rather may be described as a local policy which, from the northern Italian cities, developed and contaminated the rest of the country. From the 1980 s this approach began to be supported and funded by a number of 'Regioni.' 108 Regional Laws were enacted leading to the institutionalization of the 'campo nomade,' as we know it today. It is because of a political process, from local experiments to national policy, that Italy has slowly turned into a 'paese dei campi' (campland). The idea of the Romani peoples as being 'nomadic' and the creation of the camp as an institutional measure to protect this 'cultural trait' were the main features of these laws. ${ }^{109}$ On the one hand, this represented a belated attempt to respond to the presence of the Romani peoples in Italy, an embryonic mechanism for regulating the discriminatory episodes that were affecting them. On the other hand, though, it reinforced stereotypical ideas laid the foundation for the association 'Romanies' and 'camps.'

The following fragment of the interview given by one of the social assistants working inside the 'nomad camps' is indicative of the situation:

In the Italian mainstream mentality the 'Zingari' (Gypsies) were always considered as nomads. Before the Second World War, though, only a part of them were still nomadic or semi-nomadic. These people in particular were devoted to the 'spettacolo viaggiante' (travelling exhibitions/performances), horse-trading, metal handicrafts, etc., and were defined as 'girovaghi' (itinerant/wanderer) by the Italian mainstream society. After the end of the war, a process of sedentarisation took place, the economic boom, etc., until the arrival of the first Romani peoples from the former Yugoslavia took place. When the Italian government issued the Regional Laws, this was done with the earlier nomadic or semi-nomadic Romani peoples in mind. ${ }^{110}$

\footnotetext{
104 I. Clough Marinaro, 'Between surveillance and exile: Biopolitics and the Roma in Italy,' Bulletin of Italian Politics, Vol. 1, No. 2, 2009, pp. 265-287.

105 Clough Marinaro and Sigona, op. cit., p. 587.

106 UNAR, Vai oltre i pregiudizi, p. 42.

${ }^{107}$ L. Piasere, I Rom d'Europa: Una storia moderna [The Roma of Europe: A modern history], Rome, Italy: Laterza, 2004, p. 86.

${ }^{108}$ Italy is administratively subdivided into twenty regions or regional administrations.

109 Fiorucci, op. cit., pp. 34-35.

110 Ibid., p. 35.
} 
In fact, although only a small percentage of the Romani peoples live in camps today; those number residing in camps is approximately 40 thousand people, which corresponds to between one fourth and one fifth of the entire population of this minority group ${ }^{111}-$ the 'rom/nomade/zingaro' that policy makers have in mind is an abstraction, rather than an actual person, created from stereotypical images.'112

According to Bravi and Sigona, the very first form of recognition and protection of the 'right to nomadism' in Italy can be dated back to October 1973 when the Ministero dell'Interno issued the 'Circolare' (internal administrative document) MIAC no. 17/73.113 This document was directed to the mayors of the Italian cities, especially those in the northern regions, that at that time had started to adopt 'divieti di sosta' (no parking areas) against the Romani peoples. Although this act required local administrations, among other things, to abolish these discriminatory bans and to facilitate the temporary stay of the Romani peoples, ${ }^{114}$ it also had negative consequences for them. It started to address the Romani issue in terms of 'Problema Nomadi' (Nomads Problem), ${ }^{115}$ and the recommendations contained in the MIAC no. $17 / 73$ also sowed the seeds of the future 'camp strategy,' leading to the creation of special campsites. ${ }^{116}$ With the introduction of these new legislative measures, the Romani peoples were given the possibility of settling temporarily in specific areas.

These early types of encampments already resembled the modern 'nomad camps.' They were delimited areas placed at the urban outskirts in accordance with the "piani regolatori comunali' (urban planning regulations), which established their location, size and settlement standards. ${ }^{117}$ Moreover, the rules regulating these places were quite rigid and inhabitants were subjected to a number of limitations. For instance, school attendance for children was compulsory and evasion of this obligation might lead to exclusion of the whole family from accessing the campsite. The police had the mandate to enforce special control over the camp areas at any time and all inhabitants had to be in possession of regular identity papers, etc. ${ }^{118}$ According to Sigona, ${ }^{119}$ since the 1970 , all government interventions, either regarding the education, sociality, health, or employment of the Romani peoples were centred on the existence of the 'camp.' Basically, from the initial intention of providing a culturally protective device for this minority group, this policy gradually turned into an institutional instrument of segregation and control over them.

\section{Conclusion}

No effective policies have been enacted in order to guarantee social inclusion of the Romanies within Italian mainstream society. According to Clough Marinaro, 'the early postwar decades saw the persistence both of public safety approaches and the introduction of

\footnotetext{
${ }^{111}$ Commissione Diritti Umani del Senato, op. cit., p. 48.

${ }_{112}$ N. Sigona, Lo scandalo dell'alterità: Rom e sinti in Italia [The scandal of otherness: Rom and Sinti in Italy], Nuovadimensione, Portogruaro, 2007, cited in Fiorucci, op. cit., p. 35.

113 Bravi \& Sigona, op. cit., p. 863.

${ }_{114}$ R. Maggian, Guida al welfare italiano: Dalla pianificazione sociale alla gestione dei servizi [A guide to the Italian welfare: From social planning to service management], Maggioli Editore, Santarcangelo di Romagna, Rimini, 2011, pp. 217-218.

115 Ministero dell'Interno, op. cit., p. 16.

${ }^{116}$ Sigona, Figli del ghetto, p. 69.

117 Nessun luogo è lontano, 'Rom e Sinti, dalla legalità alla coesione sociale,' Appunti Arancioni, p. 4, 2008, <http://www.nessunluogoelontano.it/nuovosito/index.php?option=com_docman\&task=searchresult\&order

$=$ dmname\&ascdesc $=$ ASC\&Itemid $=48>$, accessed 5 July 2014, p. 7.

${ }^{118}$ Sigona, Figli del ghetto, p. 57.

119 Ibid., p.56.
} 
legislative obstacles to nomadism.' ${ }^{120}$ Still, during the 1970 s the government started to experiment some forms of cultural protection for 'nomadic people.' This well-established controlling trend has remained unchanged ever since.

It was not until recently that the crimes committed by the Fascist regime during the Second World War were thoroughly analysed and contested. For many years it was commonly believed that Fascism targeted Romani peoples 'exclusively as a problem of public order and not as a racial issue, unlike the Nazi regime.' 121 This assumption was a consequence of a wellrooted belief in a sort of intrinsic goodness of the Italian people. ${ }^{122}$ The growth of national patriotism is now playing a key role in the emergence of an historical amnesia, which has been leading to historical revisionism as well.

The decision to implement the 'Nomad Emergency,' which conceptualised the Romanies as 'nomads' and a 'natural disaster,'123 was used by governments merely as a mean of acquiring more power and introducing an authoritarian approach towards Romani individuals and communities. This situation has slowly become the 'objectification of a state of exception,'124 as theorised by Agamben, ${ }^{125}$ and served to cover a prolonged situation of institutional neglect.

Decay and abandonment, which by now constitute a common feature in the 'nomad camps,' are generally the result of the institutional immobility and indifference to the living conditions of those who have been once defined as 'popoli delle discariche' (peoples of the dumps). ${ }^{126}$ This in turn set the premises to implement emergency measures-not proportionate to the degree of threat-, while blaming Romani peoples themselves. The construction of the 'Nomad Emergency' is thus the juridical foundation for its proclamation. ${ }^{127}$ Curiously in this context, 'no emergency legislation was passed to deal with the emergency of corruption.' 128

The existence of strong divisions within the country and the concurrent explosion of international events have always pushed the ruling class to establish highly controlling and often unconstitutional policies. Political corruption, lack of transparency on a systematic level, but also the presence of ongoing debates surrounding the definition of Italian identity and history, defined as 'culture wars' by Chamedes, ${ }^{129}$ all represent corollary issues which might provide an explanation about the recent authoritarian approach towards the Romani peoples, together with discriminatory laws and policies against immigrants. ${ }^{130}$ They could all be interpreted as an indirect consequence of the government's incapacity to deal with a shameful past and its unbroken ties. According to Ventresca, for instance, the existence of "gaps" in Italian collective memory [...] do constitute a deformed or immature "civil conscience" that, in turn, harms the health of Italy's democratic polity.' $13^{1}$ This has allowed

\footnotetext{
120 Clough Marinaro, op. cit., p. 273.

${ }^{121}$ Ibid., p. 272.

122 Favero, op. cit., p. 140.

123 Fiorucci, op. cit., p. 34.

124 Bravi \& Sigona, op. cit., p. 858.

125 Agamben, op. cit., p. 168.

${ }^{126}$ L. Piasere, Popoli delle discariche: Saggi di antropologia zingara (2nd ed.) [Peoples of the dumps: Essays in Gypsy anthropology],CISU, Rome, Italy, 2005.

127 Clough Marinaro, op. cit., p. 269.

${ }^{128}$ P. Davigo and G. Mannozzi, La corruzione in Italia, Roma-Bari, Laterza, 2007, cited in Vannucci, op. cit., pp. 249250.

129 G. Chamedes, Culture wars in Italy from the Risorgimento to today [PDF document], n.d., <http://scholar.harvard.edu/files/gchamedes/files/chamedes_culture_wars_in_italy.pdf.>, accessed 8 July 2013 , p. 1. 130 Clough Marinaro, op. cit. p. 275.

${ }^{131}$ Ventresca , A comparative history, p. 17.
} 
racism to re-emerge, as Re argued, 'resuscitating the proverbial myth of Italian kindness and moral superiority.' 132

On May 2, 2013 the Court of Cassation, Italy's highest court, upheld the ruling which had declared unfounded, unwarranted and unlawful the 'Emergenza Nomadi.' The court thus rejected the government's appeal against the Council of State's finding from November 2011. ${ }^{133}$ Despite this, at the time of completing this article (June 2014), political and ideological attacks on Roma remain at frightening levels as conveyed in a recent report issued by the ERRC: housing, employment, education and health projects are still inadequate to promote real inclusion of Roma. ${ }^{134}$ Most importantly, an emergency approach, based on 'camp policy' and forced evictions, remains in place

${ }^{132}$ Re, op. cit., p. 1.

133 European Roma Rights Centre. End of the Road for Italy's Illegal State of Emergency, 2013, <http://www.errc.org/article/end-of-the-road-for-italys-illegal-state-of-emergency/4137>, accessed 17 May, 2013 , para. 1.

134 European Roma Rights Centre, Written comments by the European Roma Rights Centre, concerning Italy to the Human Rights Council, within its universal periodic review, for consideration at the 2oth session (27 October to 7 November 2014), 2014, <http://www.errc.org/cms/upload/file/italy-un-upr-submission-20-march-2014.pdf>, accessed 10 April, 2014, p. 7. 